\title{
Exchange Rate Elasticity of Chinese Export and Firms' Productivity: A Study based on Matched Firm-level Data
}

\author{
Ting Chen \\ Department of International Economics and Business, Xiamen University, Xiamen City, P. R. China \\ chenting124@163.com
}

Keywords: Exchange rate elasticity of export; RMB exchange rate; Total factor productivity

\begin{abstract}
This paper employed matched data for the first time to estimate firms' exchange rate elasticity of export and analyze how total factor productivity (TFP) affect firms' exchange rate elasticity of export. Using highly disaggregated matched data from Chinese transaction-level trade data and firm-level production data from 2000 to 2006, we construct firm-level real effective exchange rate (REER) and TFP. We find that when the firms' TFP is at the mean level, the exchange rate elasticity of export is -0.093 . Furthermore, when the TFP increases one standard deviation, the exchange rate elasticity of export is -0.062 . The results indicate that the high-performance firms are less sensitive to react to an appreciation of exchange rate. When we divided the firms into five groups by firm's productivity percentiles, or when we use labor productivity to replace the TFP, the results remain robust.
\end{abstract}

\section{Introduction}

The study on exchange rate and trade in international economics has for a long time focused on the exchange rate elasticity of export, in some classic economic models, the exchange rate elasticity of export is a crucial factor to affect the benefit of trade $[1,2,3]$. However, most of studies are not accurate because they used aggregate data, which assume all the firms are the same and they face the same exchange rate volatility. At first, country-level time series data is widely used in this field [4,5,6 ]; Then from 1990s, more and more industry-level data was used [7,8,9 ]; In recent years, more and more firm-level data was used due to the development of firm heterogeneity theory and accessibility of micro-data [10,11 ]. But there is very little evidence that links exchange rate elasticity to Chinese firm-level data.

The past three decades have seen a rapid increase in china's trade with the world, china has become the biggest exporter in the world, and export is very significant to China's economic development, it is important to estimate the exchange rate elasticity of export accurately for Chinese firms and the government. In this paper, we first calculate the firm-level real effective exchange rate (REER) with a rich disaggregate Chinese data, then focus on how RMB exchange rate volatility affect the export of firms, we also analyzes the heterogeneous reaction of exporters with different total factor productivity (TFP). Our key finding is that, at one hand, exchange rate elasticity of export is-0.093 when take the average of firms' TFP, which means when the firm-level exchange rate increase 10\%, the export sales of the firm will decrease $0.93 \%$; At the other hand, when the TFP of the exporter increase one standard deviation, the exchange rate elasticity of export down to -0.062. When we divided the firms into five groups according to the TFP percentiles, the exchange rate elasticity of firms with the highest $20 \%$ FTP is -0.060 , which is 0.094 lower than the firms with the lowest $20 \%$ FTP. When we use the Labor Productivity (value added per worker) to replace the TFP, the results are still robust.

\section{Data and model}

In this paper, we rely on the following two disaggregated, large panel data sets: firm-level production data, and product-level trade data. Firm-Level production data are collected and maintained by China's National Bureau of Statistics (NBS) in an annual survey of manufacturing enterprises, the 
data set covers two types of manufacturing firms, all state-owned enterprises (SOEs) and non-SOEs whose annual sales exceed RMB 5 million and contains more than 100 variables, we filter this data set following [12,13]. We need the variable fixed assets in this paper, unfortunately, firm-level production data don't contain it, so we estimate this variable according to $K_{t}=I_{t}+(1-\delta) * K_{t-1}$, $\mathrm{K}_{\mathrm{t}}$ is gross fixed assets, I is investment, and $\delta$ is depreciation rate of fixed assets.

The disaggregated product-level trade transaction data from 2000 to 2006 are obtained from China's General Administration of Customs. It records a variety of information of all the exporters in china, including trading price, quantity, trade partner, address, phone number, zip and value at the HS eight-digit level.

Although both the data have firm codes, the coding system in each data set is completely different. Hence, the firm code cannot serve as a unique variable to match the two data sets. To overcome this difficulty, we following $[12,14]$. First, we match the two data by using the firm's Chinese name, that is, if a firm has an exact Chinese name in both data set, it should be the same firm. To increase the qualified matching number of firms to as many as possible, we then match the two data by using the firm's telephone number and zip. After merging both product-level trade data and firm-level production data, I finally obtain the matched firms, as described carefully in table 1.From Table 1 we can see that the merged firms from 16136 in 2000 to 47346 in 2006 when we match the two data set by using the firm's Chinese name; and the merged firms increase to 19755 in 2000 to 49624 in 2006 when we match the two data sets using the two methods at the same time.

Table 1 Matched Statistics: Number of Firms

\begin{tabular}{|c|c|c|c|c|c|c|c|}
\hline \multirow{2}{*}{$\begin{array}{l}\mathrm{Y} \\
\text { ear }\end{array}$} & \multicolumn{2}{|l|}{ Trade data } & \multicolumn{2}{|c|}{ Production Data } & \multicolumn{2}{|c|}{ Matched Data } & \multirow[b]{2}{*}{$\begin{array}{l}\text { Matc } \\
\text { hed } \\
\text { Firms } \\
\quad(7) \\
\end{array}$} \\
\hline & $\begin{array}{l}\text { Transaction } \\
\text { s } \\
\quad(1)\end{array}$ & $\begin{array}{c}\text { Firms } \\
\text { (2) }\end{array}$ & $\begin{array}{l}\text { Raw } \\
\text { Firms } \\
\text { (3) }\end{array}$ & $\begin{array}{c}\text { Filtere } \\
\text { d Firms } \\
(4)\end{array}$ & $\begin{array}{l}\text { Match } \\
\text { variable } \\
\text { one } \\
\quad \text { (5) }\end{array}$ & $\begin{array}{l}\text { Match } \\
\text { variable } \\
\text { two } \\
(6)\end{array}$ & \\
\hline 20 & $10,586,696$ & 80,23 & 162,8 & 56192 & 16136 & 9084 & 19755 \\
\hline 00 & & 2 & 83 & & & & \\
\hline 20 & $12,667,685$ & 87,40 & 169,0 & 53951 & 19108 & 9425 & 22622 \\
\hline 01 & & 4 & 31 & & & & \\
\hline 20 & $14,032,675$ & 95,57 & 181,5 & 70028 & 21799 & 9165 & 25106 \\
\hline 02 & & 9 & 57 & & & & \\
\hline 20 & $18,069,404$ & 113,1 & 196,2 & 79032 & 30799 & 8157 & 33682 \\
\hline 03 & & 47 & 22 & & & & \\
\hline 20 & $21,402,355$ & 134,8 & 277,0 & 84487 & 39747 & 7934 & 42192 \\
\hline 04 & & 95 & 04 & & & & \\
\hline 20 & 24,889,639 & 136,6 & 271,8 & 146550 & 39966 & 12991 & 44039 \\
\hline 05 & & 04 & 35 & & & & \\
\hline 20 & $16,685,377$ & 197,8 & 301,9 & 154890 & 47346 & 6913 & 49624 \\
\hline 06 & & 06 & 60 & & & & \\
\hline
\end{tabular}

Notes: Column (1) reports number of observations of HS eight-digit monthly transaction-level trade data from China's General Administration of Customs by year. Column (2) reports number of firms covered in the transaction-level trade data by year. Column (3) reports number of firms covered in the firm-level production dataset compiled by China's National Bureau of Statistics without any filter and cleaning. By contrast, Column (4) presents number of firms covered in the firm-level production dataset with careful filter. Accordingly, Column (5) reports number of matched firms using exactly identical company's names in both trade dataset and filtered production dataset. Column (6) reports number of matched firms using exactly identical zip code and phone numbers in both trade dataset and filtered production dataset. Column (7) reports number of matched firms using exactly identical company's names and exactly identical zip code and phone numbers in both trade dataset and filtered production dataset.

After filtering these data, we estimate the firm's TFP use Olley-Pakes (OP) method, which is a standard method in the economics references, this approach assumes that investment is more actively 
responsive to unobserved productivity, and consider that the firms with low productivity will exit, it is capable of controlling for the possible simultaneity bias and selection bias caused by regular ordinary least squares (OLS) estimates.

The most important variable in our paper is REER, we calculate it following [15], which is shown in equation (1):

$$
R E E R_{i t}=100 * \prod_{k=1}^{n}\left(\frac{E_{k t}}{E_{k 0}} \frac{C P I_{c t}}{C P I_{k t}}\right)^{w_{i k t}}, \sum_{k=1}^{n} w_{i k}=1
$$

$E_{k t}$ is nominal exchange rate of country $k$ at year $t$, which means one RMB can exchange $E_{k t}$ units country c's currency, $\mathrm{E}_{\mathrm{k} 0}$ is nominal exchange rate of country $\mathrm{k}$ at base period, CPIct is China's consumer price index in year $\mathrm{t}$, and $\mathrm{CPI}_{\mathrm{kt}}$ is country c's consumer price index in year $\mathrm{t}, \mathrm{w}_{\mathrm{ikt}}$ is the weight which equals to firm i's export value to country $\mathrm{k}$ in year $\mathrm{t}$ divided by firm i's total export value in year t. When REER increasing, that means RMB is appreciating, otherwise, RMB is depreciating. All the exchange rate data we use is come from International Financial Statistics and CPI data is come from World Bank's world development index (WDI).

Table 2 is the statistical description of the relevant variables, using highly disaggregated matched data from Chinese transaction-level trade data and firm-level production data from 2000 to 2006. Table 2 shows that, in the sample year, the log of firm's export value mean is 13.74, the $\log$ of firm-level real effective exchange rate mean is 4.63, the log of firm-level Olley-Pakes total factor productivity mean is 1.32, the log of firm-level Labor Productivity is 3.87. We also show the standard deviations, minimum values, median values and the maximum values of the relevant variables

Table 2 Statistical description of the relevant variables

\begin{tabular}{lllllll}
\hline Variables & Mean & S.D. & Min. & Median & Max. & Obs. \\
\hline Log of export value & 13.74 & 2.120 & 0 & 14 & 23.64 & 200000 \\
Log of REER & 4.630 & 0.200 & 2.790 & 4.620 & 12.78 & 200000 \\
Log of OP TFP & 1.320 & 0.280 & -5.330 & 1.350 & 2.380 & 200000 \\
Log of Labor Productivity & 3.870 & 1.080 & -5.700 & 3.800 & 11.10 & 200000 \\
\hline
\end{tabular}

Sources: Author calculated according to transaction-level trade data and firm-level production dataset from 2000 to 2006.

This paper employed the econometric method proposed in $[15,16]$ to analyze how total factor productivity (TFP) affects Chinese firms' exchange rate elasticity of export. The econometric model we use in this paper is in the form of equation (2):

$$
\ln \operatorname{EXP}_{i t}=\alpha+\beta_{1} \ln \left(R E E R_{i t}\right)+\beta_{2} \ln \left(R E E R_{i t}\right) \times \ln \left(T F P_{i t}\right)+\mu_{i}+\psi_{t}+\xi_{i t}
$$

In equation (2), EXPit is Chinese firm i's export value at year t; REER $\mathrm{it}_{\mathrm{t}}$ is firm i's real effective exchange rate in year $t$; $\mathrm{TFP}_{\text {it }}$ is total factor productivity of firm $\mathrm{i}$ at year $\mathrm{t}$, which is estimated by OP approach. ${ }^{\mu_{i}}$ is the unobserved firm characteristics, it is not changed over time; ${ }^{{ }_{t}}$ is the unobserved variables that is changed over time; $\alpha$ is the intercept item; $\xi_{\text {it }}$ is the residual item. Due to the interaction item, we can derivate both sides by REER to get: the exchange rate elasticity of export= $\beta_{1}+\beta_{2} \times \ln \left(T F P_{i t}\right)$, which means the exchange rate elasticity is related to the firm's productivity.

\section{Empirical results and analysis}

This paper used Ordinary Least Square (OLS), Random Effect (RE) and the Fixed Effect (FE) methods to estimate the results. In order to know how total factor productivity (TFP) affects firms' exchange rate elasticity of export, we first calculated the exchange rate elasticity of export when the firms' TFP is at the mean level. Then we estimated how the exchange rate elasticity of export changed when the TFP increases one standard deviation. Table 3 shows that when the firms' TFP is at the mean level, the exchange rate elasticity of export is -0.269 under OLS method, is -0.124 under RE method, is -0.093 under FE method. When the TFP increases one standard deviation, the exchange 
rate elasticity of export is -0.224 under OLS, is -0.091 under RE, is -0.062 under FE. The results indicate that the high-performance firms are less sensitive to react to an appreciation of exchange rate.

Table 3 Baseline Results

\begin{tabular}{llll}
\hline & $(1)$ & $(2)$ & $(3)$ \\
& OLS_TFP & RE_TFP & FE_TFP \\
\hline Ln REER & $-0.559^{* * *}$ & $-0.335^{* * *}$ & $-0.295^{* * *}$ \\
& $(0.024)$ & $(0.019)$ & $(0.022)$ \\
Ln REER*Ln TFP & $0.214^{* * *}$ & $0.156^{* * *}$ & $0.149^{* * *}$ \\
& $(0.004)$ & $(0.003)$ & $(0.003)$ \\
Constant & $15.019^{* * *}$ & $14.008^{* * *}$ & $14.195^{* * *}$ \\
& $(0.110)$ & $(0.088)$ & $(0.101)$ \\
mean TFP $\rightarrow$ mean+s.d TFP & $-0.269 \rightarrow-0.224$ & $-0.124 \rightarrow-0.091$ & $-0.093 \rightarrow-0.062$ \\
Observations & 196122 & 196122 & 196122 \\
\hline
\end{tabular}

Notes: The value in the brackets are the robust standard errors of the estimators. The symbol "***, **,*" indicates significance at the $1 \%, 5 \%, 10 \%$ levels respectively.

To ensure the robustness of the results, Table 4 shows the exchange rate elasticity of export by firms with different productivities. We ordered the firms by their TFP from big to small, divided the firms into five groups according to the TFP percentiles. The benchmark group is the firms with the lowest $20 \%$ (the productivity ranking is below $80 \%$ ) FTP, its exchange rate elasticity is -0.154 . Top $80 \%$ TFP * LnREER is the firms with the productivity ranking between $60 \%$ and $80 \%$, its exchange rate elasticity is 0.031 lower than the baseline group. Top60\% TFP * LnREER is the firms with the productivity ranking between $40 \%$ and $60 \%$, its exchange rate elasticity is 0.057 lower than the baseline group. Top $40 \%$ TFP * LnREER is the firms with the productivity ranking between $20 \%$ and $40 \%$, its exchange rate elasticity is 0.079 lower than the baseline group. Top20\% TFP * LnREER is the firms with the highest $20 \%$ FTP, its exchange rate elasticity is $-0.060(=-0.154+0.094)$, which is 0.094 lower than the baseline group.

Table 4 Robustness Percentiles

\begin{tabular}{ll}
\hline & \multicolumn{1}{c}{ Divided into five groups by } \\
& TFP \\
\hline LnREER & $-0.154^{* * *}$ \\
& $(0.022)$ \\
Top80\% TFP * LnREER & $0.031^{* * *}$ \\
& $(0.002)$ \\
Top60\% TFP * LnREER & $0.057 * * *$ \\
& $(0.002)$ \\
Top40\% TFP * LnREER & $0.079 * * *$ \\
& $(0.003)$ \\
Top20\% TFP * LnREER & $0.094 * * *$ \\
Benchmark group $\rightarrow$ Top group & $-0.154 \rightarrow-0.060$ \\
Observations & 199867 \\
\hline
\end{tabular}

Notes: The value in the brackets are the robust standard errors of the estimators. The symbol "***, **,*" indicates significance at the $1 \%, 5 \%, 10 \%$ levels respectively.

This paper also use the Labor Productivity (value added per worker) to replace the TFP following $[16,17]$ for the robustness of results. Table 5 shows that when the firms' Labor Productivity is at the mean level, the exchange rate elasticity of export is- 0.292 under OLS method, is -0.168 under RE method, is -0.145 under FE method. When the Labor Productivity increases one standard deviation, the exchange rate elasticity of export is -0.288 under OLS, is -0.160 under RE, is- 0.133 under FE. The 
results also indicate that the high-performance firms are less sensitive to react to an appreciation of exchange rate.

Table 5 Robustness: Labor Productivity

\begin{tabular}{llll}
\hline & $(1)$ & $(2)$ & $(3)$ \\
& OLS_Lab & RE_Lab & FE_Lab \\
\hline Ln REER & $-0.336^{* * *}$ & $-0.268^{* * *}$ & $-0.279^{* * *}$ \\
& $(0.024)$ & $(0.019)$ & $(0.022)$ \\
Ln Lab_Prod.* Ln REER & $0.015^{* * *}$ & $0.035^{* * *}$ & $0.046^{* * *}$ \\
& $(0.001)$ & $(0.001)$ & $(0.001)$ \\
Constant & $15.020^{* * *}$ & $14.027^{* * *}$ & $14.199^{* * *}$ \\
& $(0.110)$ & $(0.088)$ & $(0.101)$ \\
Mean Prod. $\rightarrow$ mean+s.d Prod. & $-0.292 \rightarrow-0.288$ & $-0.168 \rightarrow-0.160$ & $-0.145 \rightarrow-0.133$ \\
Observations & 196487 & 196487 & 196487 \\
\hline
\end{tabular}

Notes: The value in the brackets are the robust standard errors of the estimators. The symbol "*** , **,*" indicates significance at the $1 \%, 5 \%, 10 \%$ levels respectively.

\section{Conclusions}

Using two disaggregated large panel data sets, firm-level production data and product-level trade data, we constructed the firm-level REER and the firm-level TFP with OP approach, and then estimated how TFP affect firms' exchange rate elasticity of export. We find that the firm-level REER is significantly different between firms due to their different combination of export destination. In particular, the appreciation of RMB does have negative effects on firm's export, but the firm's high productivity can significantly increase firm's ability to withstand the exchange rate movements, this conclusion is consistent with Belgium following [16]. As one of the troika of economic growth, export is vital to GDP and employment in China. We are reluctant to see the negative impact of the appreciation of RMB exchange rate on export, but we cannot control the outside shocks, then increase the firm's own productivity should be the optimal choice to resist shocks. This paper emphasizes how the firm's productivity affects the exchange rate elasticity of export, and finds that the improvement of firm's productivity can indeed against the exchange rate shocks, and the higher the firm's productivity, the stronger the firm's ability to resist shocks.

\section{References}

[1] Krugman, P. R: Journal of International Economics Vol.9 (1979), p. 469-479.

[2] Bernard, A. B., Eaton, J., Jensen, J. B., and Kortum: American Economic Review Vol.93 (2003), p. 1268-1290.

[3] Melitz, M. J.: Econometrica Vol.71 (2003), p. 1695-1725.

[4] Kenen, P. and Rodrik, D: The Review of Economics and Statistics Vol.68 (1986), p.311-315.

[5] Baxter, M. and Stockman, A: Journal of Monetary Economics Vol. 23(1989), p.377-400.

[6] Lastrapes, W. D. and Koray, F: Journal of International Money and Finance Vol. 9(1990), p.402-423.

[7] Campa, J. and Goldberg, L: Journal of International Economics Vol. 38(1995), p.297-320.

[8] Goldberg, L., Tracy, J. and Aaronson, S.R: American Economic Review Vol. 89(1999), p.204-210.

[9] Marquez Jaime and John Schindler: Review of International Economics Vol.15 (2007), p.837-853. 
[10] Park, A., Yang, D., Shi, X., and Jiang, Y: The Review of Economics and Statistics Vol.92 (2010), p.822-842.

[11] Chatterjee A, Dix-Carneiro R, Vichyanond J: American Economic Journal: Economic Policy Vol. 5(2013), p. 77-110.

[12] Yu Maojie: forthcoming in Economic Journal (2014)

[13] Xiaodong Lu, Yujun Lian: China Economic Quarterly Vol.11 (2012), p.541-558.In Chinese.

[14] Tang H, Zhang Y: CESifo Economic Studies Vol.58 (2012), p. 671-702.

[15] Hongbin Li, Hong Ma, Yanyan Xiong, Yuan Xu: Journal of Financial Research Vol.368 (2011), p.1-16. In Chinese.

[16] Berman, N., P. Martin and T. Mayer: Quarterly Journal of Economics, 2012, 127: 437-492.

[17] Lu, Dan: University of Chicago Working Paper, 2010. Information on http://citeseerx.ist.psu.edu/viewdoc/download?rep=rep1\&type=pdf\&doi=10.1.1.186.3652 